\title{
Generation of Solid Recovered Fuel from the Separate Fraction of Pre-composted Materials (Sewage Sludge and Biomass Residues)
}

\author{
Irina Kliopova, Kristina Makarskienė \\ Kaunas University of Technology, Institute of Environmental Engineering
}

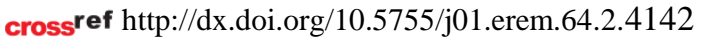

(Received in April, 2013; accepted in June)

\begin{abstract}
The paper presents results of the research which was done when implementing one stage of the PF7 program project "Polygeneration of energy, fuels, and fertilizers from biomass residues and sewage sludge (ENERCOM)" (No TREN/FP7/EN/218916) - the study on peat and / or sawdust substitution potential for the solid recovered fuel (SRF) of compost. The compost is produced of pre-treated sewage sludge and biomass residuals in a "Soil-Concept" plant (Luxemburg). During ENERCOM project implementation the laboratory analysis of different compost fractions shows that fraction 10-40 mm of pre-composted materials can be used for SRF production. The equipment for SRF production in a pellet form was developed in pilot "SoilConcept". Pelleting press monitoring was carried out to evaluate real environmental indicators (EI). These EI were used for environmental impact assessment (EIA) of generating SRF and its burning for heat energy production. The method of comparison analysis was chosen for the EIA. SRF was compared to the peat fuel and sawdust. Results of technical and environmental evaluations of SRF production and its burning, comparison analysis with peat fuel and sawdust, as well as conclusions and recommendations made are presented.
\end{abstract}

Key words: Solid recovered fuel, sewage sludge, biodegradable waste, sawdust, pea fuel, environmental impact assessment.

\section{Introduction}

Sewage sludge production differentiated significantly among various countries in the EU, the highest sewage sludge production was observed in Germany $2170 * 10^{3}$ t/year of dry solids (DS); noticeably lower sewage sludge production was in Lithuania $-66 * 10^{3} \mathrm{t} /$ year of DS, but nearly the same amount equivalently fell for population per year in both countries - approx. $28 \mathrm{~kg}$ (Kelessidis and Stasinakis 2012).

During 2008-2012, the Institute of Environmental Engineering of Kaunas University of Technology (KTU APINI) participated in the PF7 program "Energy" of the project "Polygeneration of energy, fuels and fertilizers from biomass residues and sewage sludge (ENERCOM)" (No TREN/FP7/EN/218916). Project coordinator: Ifas Institute for Applied Material Flow Management (Germany). Project partners: Soil-Concept S.A.
(Luxembourg), LEE (Luxembourg), Bisanz Anlagenbau GmbH (Germany), BIOS Bioenergiesysteme GmbH (Austria), KTU APINI (Lithuania), Kuhbier Law Firm (KLF) (Belgium), B.A.U.M. Consult GmbH (Germany).

The aim of the project was to demonstrate highefficient poly-generation of electricity, heat, solid fuels and high-value compost/fertilizers from sewage sludge and greenery waste mixed with biomass residues. The project concept allows achieving high overall energy efficiency by:

- mixing sewage sludge with greenery waste and biomass residues, and using low-temperature environmental heat and heat from the composting process for drying sewage sludge;

- $\quad$ highly efficient gasification process; 
- $\quad$ saving transport energy due to a better overall material flow management inherent to the concept (ENERCOM).

The compost production company, owned and operated by the consortium partner Soil-Concept in Luxemburg, was chosen as a pilot company. Aerobic treatment with forced air supply methods is used for compost production from sewage sludge, greenery waste and biomass residues. One of the goals of the ENERCOM project was to assess the possibilities of producing solid recovered fuel (SRF) from the precomposting of input materials: stabilized sewage sludge, municipal green waste (grass, branches, etc.) and bark. These input pre-composted materials are mixed and dried in concrete silos, i.e. biological drying.

Technical and environmental possibilities to produce SRF from various compositions of raw materials (pre-composted sewage sludge, municipal green waste, sawdust and peat) in the form of pellets and briquettes were analyzed by KTU APINI researchers with the technical assistance of several Lithuanian companies and ENERCOM project partners during 2008-2010. Results of that research have already been presented (Kliopova and Makarskienè 2012).

In accordance with the data of the State Forest Survey Service, a big volume of wood waste (up to 1.3 million $\mathrm{m}^{3}$ ) is yearly produced in the forestry and wood industry in Lithuania. $\mathrm{CO}_{2}$ emissions during sawdust combustion are not reckoned in global warming. Besides, bio fuel (firewood and sawdust, in particular) is the main local renewable energy resource in Lithuania (more than $85 \%$ of the total renewable energy consumption) (Fuel and energy balance 2011).

In Europe, peat fuel is produced in Finland, Ireland, Sweden, Latvia, Estonia and Lithuania with its average annual production exceeding $38 \mathrm{TWh}$. The overall share of peat of the primary energy consumption is $3 \%$ in these countries (Peat fuel industry in the EU 2006). In Finland and in Ireland about $5-7 \%$ of the primary energy consumption is produced with peat, in Estonia and Sweden - about $0.6-1.2 \%$. In Latvia and Lithuania peat has a smaller contribution to the primary energy consumption $(<1 \%)$, main reason being that peat has a rather high $\mathrm{CO}_{2}$ emission factor $-106 \mathrm{t} / \mathrm{TJ}$, compared to oil fuel $(77.4 \mathrm{t} / \mathrm{TJ})$ and natural gas $(56.9 \mathrm{t} / \mathrm{TJ})$ (Peat fuel industry in the EU 2010).

Laboratory analysis of different fractions of precomposted materials shows that fraction 10-20-40 can be used for SRF production for the purpose of minimizing the ash content and decreasing the net calorific value (BIOS 2009).

Production of pellets by means of the precomposed material equipment (with $250 \mathrm{~kg} / \mathrm{h}$. of installed pelleting press capacity) was implemented in the pilot company during 2009-2010 for the experimental evaluation. Pelleting press monitoring was carried out for improving the technology and evaluating real environmental indicators (EI). These
IE were used for comparison of produced pellets with peat fuel and sawdust, the latter widely used in Lithuania.. The results of this research are presented and discussed in the paper.

\section{Pellets production technology in the Soil- Concept Company}

A functional scheme of a technological line of pellets production is presented in Figure 1. The following main steps of pellets production are implemented in the Soil Concept company (SoilConcept, KTU APINI 2010):

- Separation of pre- composted materials is carried out in a cylindrical separator. 10-40 mm fractions of materials are separated, since it has been defined that the compost of these fractions results in better chemical and physical characteristics for SRF production.

- Drying of pre- composted materials. The moisture content of raw materials must be reduced from approx. 40-50\% to the required level $(12-15 \%)$ before the production of pellets. In the scope of the ENERCOM project, thermal drying in the first stage of the poly-compostgasification (PCG) process is planning. Besides, heat energy for compost drying can be produced by burning the produced SRF.

- Mixing of raw materials. Additional materials can be added during this process. In 2009, during KTU APINI experiments, sawdust and peat were added in different proportions (Kliopova and Laurinkevičiūtė 2009). During that experiment, oil, e.g. rape-oil, was added: up to $1 \%$ of the total mass. The size of particles of the raw materials for pellets production may vary a lot. Therefore, raw material should be homogenized before being delivered to the technological line. For example, the precomposted materials can be mixed in an automatic stirrer as it was done during experimenting in Lithuania (Kliopova and Laurinkevičiūtè 2009).

- Milling of raw material. Usually a hammer mill is used for the milling (full homogenization) process. The capacity of the hammer mill in the Soil Concept is up to $500 \mathrm{~kg} / \mathrm{h}$.

- Pressing of pellets. Pellets are pressed using the presses with a matrix. In the Soil Concept a cylindrical matrix is used for pellets production. The capacity of the pelleting press is $250 \mathrm{~kg} / \mathrm{h}$.

- Cooling of pellets. The Soil Concept uses a cooler with a rotary star valve.

- Packing of pellets.

Monitoring of the pelleting process was performed. All received data were used for creating material and energy balances expressed in absolute units:

- Input flows: raw materials (pre-composted materials (stabilized sewage sludge and biomass residuals), rapeseed, diesel or pellets) are 
expressed in units of weight $(\mathrm{kg})$, electricity - in energy units (kWh);

- Output flows: product (pellets), water vapour, air emissions, losses or waste are expressed in units of weight $(\mathrm{kg})$.
Air emissions were evaluated only theoretically, using the emission factors estimated during SRF production in 2009 (Kliopova and Laurinkevičiūtè 2009).

Cooler $(0.75 \mathrm{~kW}) \quad$ Air

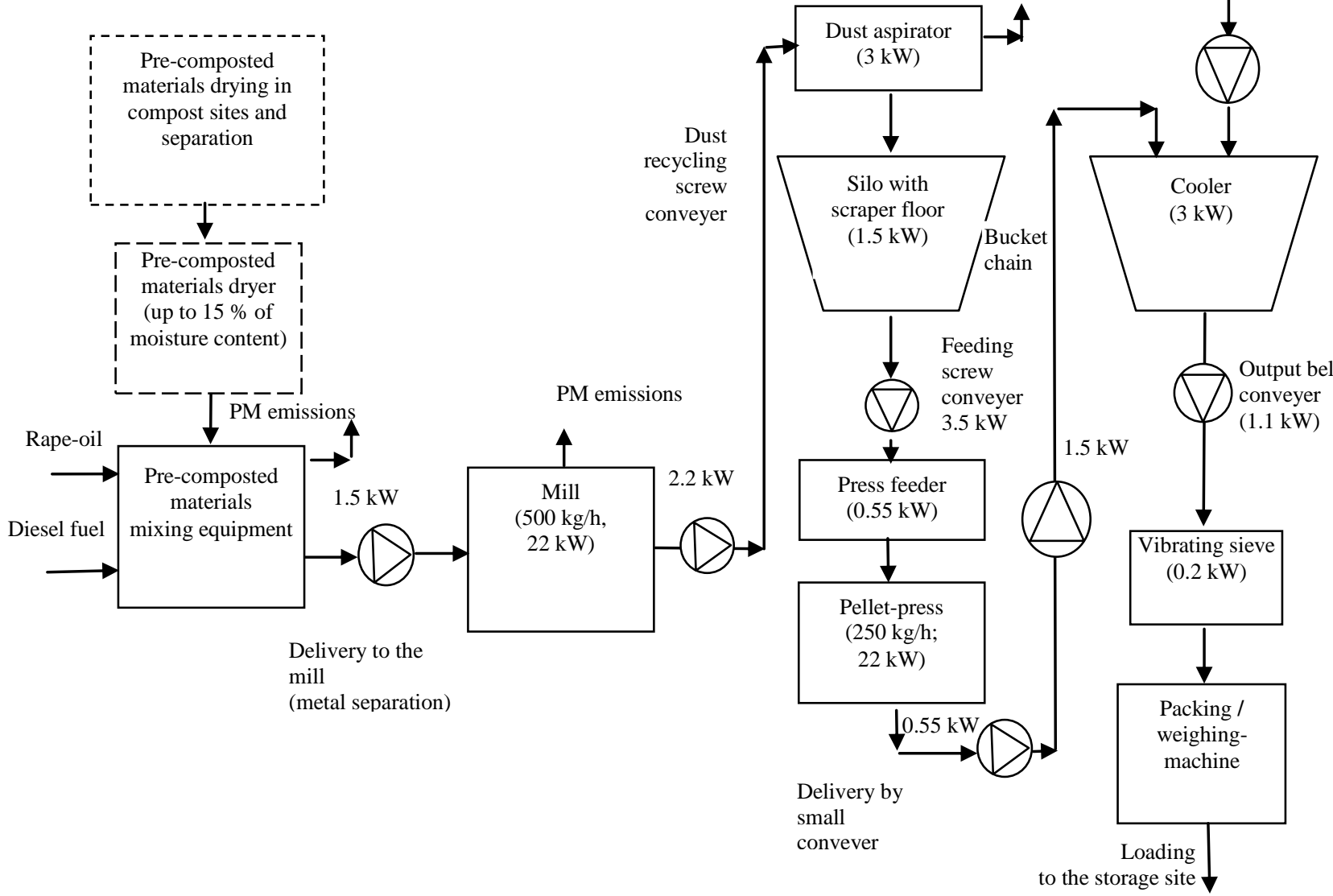

Fig. 1. Functional scheme of pelleting process in Soil-Concept

When using material and energy balances the relative EI were calculated (see Table 1).

Table 1. Relative EI of SRF production (pellets production from pre-composted materials) (Soil Concept, KTU APINI 2010)

\begin{tabular}{||l|l||}
\hline Input and output variables & EI \\
\hline $\begin{array}{l}\text { Consumption of pre-composted materials } \\
(10-40 \text { mm fraction) }(\text { moisture content } \\
\text { before mixing - } 14.5 \%), \mathrm{kg} /{ }^{1} \mathrm{~kg}\end{array}$ & 1.0840 \\
\hline Rapeseed oil consumption, $\mathrm{kg} /{ }^{1} \mathrm{~kg}$ & 0.0110 \\
\hline Amount of air emission $(\mathrm{PM}), \mathrm{kg} /{ }^{1} \mathrm{~kg}$ & 0.0313 \\
\hline Waste volume (metal parts), $\mathrm{kg} /{ }^{1} \mathrm{~kg}$ & 0.0210 \\
\hline Waste volume (losses), $\mathrm{kg} /{ }^{1} \mathrm{~kg}$ & 0.0100 \\
\hline Electric energy consumption, $\mathrm{kWh} /{ }^{1} \mathrm{~kg}$ & 0.1640 \\
\hline Diesel fuel consumption, $\mathrm{kg} / \mathrm{kg}$ & 0.0080 \\
\hline $\begin{array}{l}\text { Air emissions from mobile sources, } \\
\mathrm{kg} /{ }^{1} \mathrm{~kg}\end{array}$ & 0.0010 \\
\hline
\end{tabular}

Note: ${ }^{1} \mathrm{~kg}-1 \mathrm{~kg}$ of produced product-pellets.

Knowing the chemical composition of the recovered fuel (BIOS 2009), the net calorific value $\left(\mathrm{Q}_{\mathrm{n}}, \mathrm{kJ} / \mathrm{kg}\right)$ can be evaluated at certain moisture.
For this purpose the following formula is used (Gimbutis 1993):

$Q_{n}^{n}=339 \cdot C^{n}+1035 \cdot H^{n}-109 \cdot\left(O^{n}-S^{n}\right)-25 \cdot W^{n}$,

where:

$\mathrm{C}^{\mathrm{n}}-$ carbon content in fuel, $\%$;

$\mathrm{H}^{\mathrm{n}}-$ hydrogen content in fuel, $\%$;

$\mathrm{O}^{\mathrm{n}}-$ oxygen content in fuel, $\%$;

$\mathrm{S}^{\mathrm{n}}-$ sulphur content in fuel, $\%$;

$\mathrm{W}^{\mathrm{n}}-$ moisture content in fuel, $\%$,

Thus, the net calorific value of $12 \%$ of moisture SRF of compost (compost pellets) is equivalent to an average of $13.73 \mathrm{MJ} / \mathrm{kg}$.

\section{Methodology}

Main objectives of this research are:

- To assess whether SRF can be used, for example, instead of peat and/or sawdust for the energy production in EU countries. 
- What environmental impact of SRF production and combustion compared to peat fuel and sawdust is determined.

- Whether the amount of energy needed for the SRF production will not exceed that obtained during SRF combustion.

The study answers these questions. Therefore, the chemical composition of pre-composting materials, sawdust and peat fuel was compared.
Methodology for the environmental impact assessment (EIA) is presented in Figure 2. The methodology consists of 2 main steps:

- EIA of different fuel (peat fuel, SRF of compost, sawdust) production (fuel volume for $100 \mathrm{MWh}$ of heat energy production is analyzed);

- $\quad$ EIA of different fuel (peat fuel, SRF from precomposted materials, sawdust) burning for 100 MWh of heat energy production.

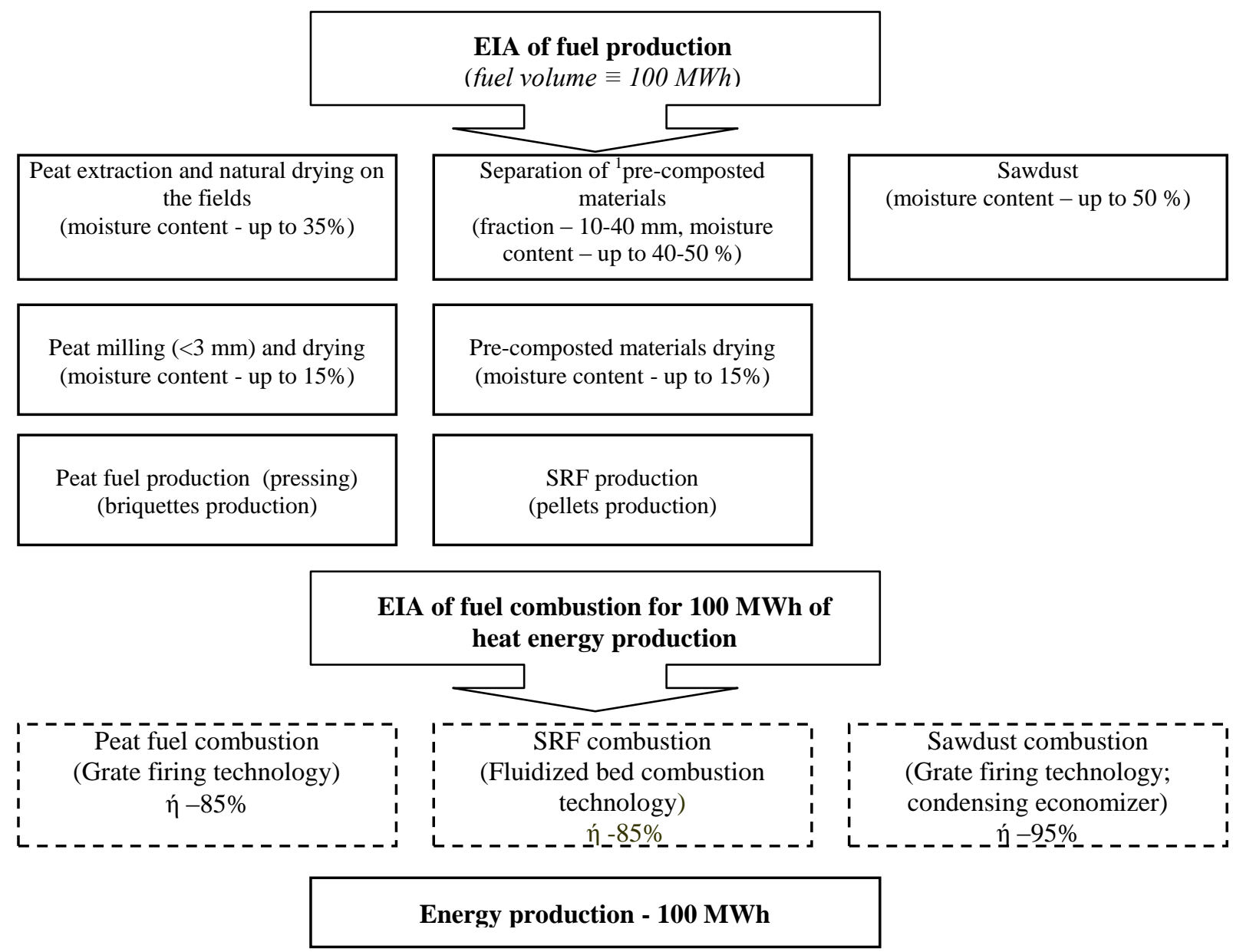

Fig. 2. Methodology for the comparison of environmental impact during different fuel (peat fuel, SRF, and sawdust) production and combustion

${ }^{1}$ Pre-composted materials: stabilized sewage sludge (about 50\%), municipal green waste (about 26\%), and other biomass residuals (mixing and biological drying during approx. 3 weeks in composting equipment).

As it is mentioned above, only peat fuel is assigned as fossil fuel; sawdust and SRF are identified as renewable resources. Therefore, the EIA of the extraction process was performed only for peat fuel. Fuel production processes (briquetting and/or pelleting) were evaluated only for peat fuel and SRF of compost.

In the second stage, it has been accepted that peat briquettes and sawdust are burnt using the grate firing technology in a combustion plant with thermal power less than $30 \mathrm{t} / \mathrm{h}$ and $85 \%$ of efficiency. In case of SRF the fluidized bed combustion (FBC) technology is applied.

Air emissions during peat briquettes (PM, CO, $\mathrm{NOx}, \mathrm{SO}_{2}$ ) and sawdust (PM, CO, NOx) burning were evaluated using the methodology, which is written in the list of methodologies for the evaluation of air emissions, approved by the Ministry of Environment of the Republic of Lithuania (13-121999 No. 395, last addition in 2008) (Set of methods 2000; Staniškis et al. 2010).

The volume of carbon dioxide $\left(\mathrm{CO}_{2}\right)$ emissions $\left(\mathrm{V}_{\mathrm{CO} 2}, \mathrm{t}\right)$ was calculated using the following formula:

$V_{\mathrm{CO}_{2}}=B \cdot Q_{n} \cdot E_{\mathrm{CO}_{2}}$,

where:

$\mathrm{B}-\quad$ burnt peat fuel volume, $\mathrm{t}$;

$\mathrm{Q}_{\mathrm{n}}-\quad$ net calorific value $\left(\mathrm{Q}_{\mathrm{n}}\right.$ (fuel peat) $\left.=15 \mathrm{MJ} / \mathrm{kg}\right)$; 
$\mathrm{E}_{\mathrm{CO} 2}-\mathrm{CO}_{2}$ emissions factor for peat burning (106 t $\left.\mathrm{CO}_{2} / \mathrm{TJ}\right)$.

The method for the evaluation of air emissions during SRF production and results of evaluation are presented in Paragraph 5.

\section{Chemical and physical characteristics of produced SRF in comparison with peat and sawdust}

Physical and chemical characteristics of peat, sawdust and pre-composted materials depend on various parameters. Characteristics of sawdust are influenced by the type of trees (deciduous or softwood). In the case of peat, the region of a peatbog, the depth of a peat layer in the peat-bog, the season of extraction, etc are relevant. Characteristics of the pre-composting materials are directly related to the variety of compost composition (green waste, sewage sludge, etc).

Table 2 presents the information about chemical characteristics of peat fuel and sawdust, which were used for SRF production from various compositions of raw materials by KTU APINI researchers in 20092010 (Kliopova and Makarskienė 2012).

Table 2 Evaluated characteristics of pre-composted materials, sawdust and peat fuel

\begin{tabular}{|c|c|c|c|}
\hline \multirow[t]{2}{*}{ Chemical characteristics } & \multicolumn{3}{|c|}{ Content of chemicals in dry matter, $\%$} \\
\hline & $\begin{array}{c}{ }^{1} \text { Pre }- \text { composted } \\
\text { materials }\end{array}$ & ${ }^{2}$ Sawdust & ${ }^{3}$ Peat \\
\hline 1 & 2 & 3 & 4 \\
\hline Ash content & 30.770 & 1.000 & 9.100 \\
\hline Hydrogen $(\mathrm{H})$ & 4.340 & 5.400 & 3.500 \\
\hline Carbon $(\mathrm{C})$ & 36.320 & 43.760 & 44.030 \\
\hline Nitrogen $(\mathrm{N})$ & 1.860 & 0.500 & 3.120 \\
\hline Sulphur (S) & 0.573 & 0.042 & 0.435 \\
\hline Chlorine $(\mathrm{Cl})$ & 0.138 & 0.007 & 0.003 \\
\hline Cadmium $(\mathrm{Cd})$ & $1.000 \cdot 10^{-4}$ & $0.400 \cdot 10^{-4}$ & $0.060 \cdot 10^{-4}$ \\
\hline Copper $(\mathrm{Cu})$ & 0.012 & $1.000 \cdot 10^{-3}$ & $0.37 \cdot 10^{-3}$ \\
\hline Lead $(\mathrm{Pb})$ & $3 \cdot 10^{-3}$ & $0.300 \cdot 10^{-3}$ & $0.380 \cdot 10^{-3}$ \\
\hline Nickel (Ni) & $5 \cdot 10^{-3}$ & 0.001 & $0.34 \cdot 10^{-3}$ \\
\hline Chromium (Cr) & 0.009 & 0.001 & 0.006 \\
\hline Hydrargyrum (Hg) & $0.12 \cdot 10^{-3}$ & $0.020 \cdot 10^{-5}$ & $0.240 \cdot 10^{-5}$ \\
\hline Zinc (Zn) & 0.065 & 0.002 & 0.009 \\
\hline Arsenic (As) & $6.620 \cdot 10^{-4}$ & $0.490 \cdot 10^{-4}$ & $6.570 \cdot 10^{-4}$ \\
\hline Manganese (Mn) & 0.052 & 0.003 & 0.150 \\
\hline Iron $(\mathrm{Fe})$ & 1.070 & 0.757 & 0.790 \\
\hline Calcium $(\mathrm{Ca})$ & 2.580 & 0.470 & 2.840 \\
\hline Magnesium (Mg) & 0.540 & 0.230 & 0.320 \\
\hline Natrium $(\mathrm{Na})$ & 0.126 & 0.030 & 0.018 \\
\hline Kalium (K) & 0.918 & 0.022 & 0.177 \\
\hline Aluminium (Al) & 1.760 & 0.378 & 0.417 \\
\hline
\end{tabular}

Comments:

${ }^{1} 10-40 \mathrm{~mm}$ fraction of pre-composted materials (about 50\% of stabilized sewage sludge, about $26 \%$ of green waste, and other biomass residuals) (up to $40 \%$ of moisture content) (BIOS 2009; Soil-Concept, KTU APINI 2010);

${ }^{2}$ Sawdust: $30 \%$ of deciduous trees sawdust and $70 \%$ of softwood (up to $50 \%$ of moisture content);

${ }^{3}$ Peat: black crumbled peat (up to $35 \%$ of moisture content).

Carbon content in dry matter of the precomposted materials amounts to higher than $36 \%$; it is only about $17 \%$ lower than the carbon content in sawdust and peat.

Ash content in dry matter of the pre-composted materials amounts to higher than $30 \%$; it is more than 3 times higher compared to the peat fuel ash content, and 30 times higher compared to the sawdust ash content, which is very low $-1 \%$.

Obviously, the pre-composted materials produce the highest chlorine, sulphur, nitrogen, heavy metals content compared to the other types of fuel. Most of heavy metals (As, $\mathrm{Cd}, \mathrm{Cr}, \mathrm{Cu}, \mathrm{Hg}, \mathrm{Ni}, \mathrm{Pb}, \mathrm{Se}, \mathrm{V}, \mathrm{Zn}$ ) are emitted in the compounds with dust. Therefore, 
high efficiency dust collectors, as electrostatic precipitators or fabric filters, are widely used to reduce the volume of heavy metals.

Referring to chemical analysis results of SRF of the year of 2009, it can be concluded that addition of sawdust or peat into SRF improves some of its characteristics: increases the net calorific volume, reduces the content of ash, $\mathrm{Cl}$, heavy metals, $\mathrm{S}$ and $\mathrm{N}$ (only in case of sawdust) (Kliopova and Makarskienè,
2012). For example, in case of addition of $10 \%$ of sawdust into pre-composted materials, the ash content decreases by $49 \%$, the $\mathrm{Cl}, \mathrm{S}$ and $\mathrm{N}$ content - by $33-$ $34 \%$, the heavy metals content - by $17 \%$ (see Table 3 , compost (II)). In case of addition of $10 \%$ of peat into pre-composted materials, the ash content decreases by $47 \%$, the $\mathrm{Cl}$ content - by $34 \%$, the heavy metals content - by $13 \%$ (see Table 3 , compost (III)).

Table 3 Comparison of chemical characteristics of pre-composted materials with different composition of raw materials

\begin{tabular}{|c|c|c|c|}
\hline \multirow{2}{*}{$\begin{array}{l}\text { Chemical } \\
\text { characteristics }\end{array}$} & \multicolumn{3}{|c|}{ Content of chemicals in dry matter, \% } \\
\hline & ${ }^{1}(\mathbf{I})$ & ${ }^{2}$ (II) & ${ }^{3}(\mathbf{I V})$ \\
\hline 1 & 2 & 3 & 4 \\
\hline Ash content & 30.770 & 15.620 & 16.150 \\
\hline Hydrogen $(\mathrm{H})$ & 4.340 & 4.990 & 4.240 \\
\hline Carbon (C) & 36.320 & 40.870 & 40.980 \\
\hline Nitrogen $(\mathrm{N})$ & 1.860 & 1.240 & 2.250 \\
\hline Sulphur (S) & 0.573 & 0.380 & 0.570 \\
\hline Chlorine $(\mathrm{Cl})$ & 0.138 & 0.092 & 0.091 \\
\hline Cadmium $(\mathrm{Cd})$ & $1.000 \cdot 10^{-4}$ & $0.740 \cdot 10^{-4}$ & $0.600 \cdot 10^{-4}$ \\
\hline Copper $(\mathrm{Cu})$ & 0.012 & 0.010 & 0.010 \\
\hline Lead $(\mathrm{Pb})$ & $3 \cdot 10^{-3}$ & $2.312 \cdot 10^{-3}$ & $2.339 \cdot 10^{-3}$ \\
\hline Nickel (Ni) & $5 \cdot 10^{-3}$ & $4.745 \cdot 10^{-3}$ & $4.615 \cdot 10^{-3}$ \\
\hline Chromium (Cr) & $9.260 \cdot 10^{-3}$ & $8.671 \cdot 10^{-3}$ & $9.708 \cdot 10^{-3}$ \\
\hline Hydrargyrum $(\mathrm{Hg})$ & $0.12 \cdot 10^{-3}$ & $0.085 \cdot 10^{-3}$ & $0.086 \cdot 10^{-3}$ \\
\hline Zinc (Zn) & 0.065 & 0.053 & 0.055 \\
\hline Arsenic (As) & $6.620 \cdot 10^{-4}$ & $5.560 \cdot 10^{-4}$ & $7.610 \cdot 10^{-4}$ \\
\hline Manganese (Mn) & 0.052 & 0.030 & 0.081 \\
\hline Iron $(\mathrm{Fe})$ & 1.070 & 0.880 & 0.892 \\
\hline Calcium (Ca) & 2.580 & 1.400 & 2.360 \\
\hline Magnesium (Mg) & 0.540 & 0.410 & 0.440 \\
\hline Natrium $(\mathrm{Na})$ & 0.126 & 0.110 & 0.107 \\
\hline Kalium (K) & 0.918 & 1.120 & 1.177 \\
\hline Aluminium $(\mathrm{Al})$ & 1.760 & 1.280 & 1.293 \\
\hline
\end{tabular}

\section{Comments:}

${ }^{l}$ Composition I: $10-40 \mathrm{~mm}$ fraction of pre-composted materials (about 50\% of stabilized sewage sludge, about $26 \%$ of green waste, and other biomass residuals) (up to 40\% of moisture content) (BIOS 2009; Soil-Concept, KTU APINI 2010);

${ }^{2}$ Composition II: $10-40 \mathrm{~mm}$ fraction of pre-composted materials (about $50 \%$ of stabilized sewage sludge, about $40 \%$ of green waste, and $10 \%$ of sawdust);

${ }^{3}$ Composition III: 10-40 mm fraction of pre-composted materials (about 50\% of stabilized sewage sludge, about $40 \%$ of green waste, and $10 \%$ of peat);

${ }^{4}$ Sawdust: $30 \%$ of deciduous trees sawdust and $70 \%$ of softwood (up to $50 \%$ of the moisture content);

${ }^{5}$ Peat: black crumbled peat (up to $35 \%$ of the moisture content).

Table 4 Comparison of SRF of pre-composted materials with the classification system of SRF (CEN/TC 343)

\begin{tabular}{||l|l|l||}
\hline $\begin{array}{l}\text { Recovered fuel } \\
\text { composition, \% }\end{array}$ & \multicolumn{2}{|l||}{$\begin{array}{l}\text { SRF of pre-composted } \\
\text { materials. }(10-40 \mathrm{~mm} \\
\text { fraction) pellets }\end{array}$} \\
\hline Recovered fuel form & value & class \\
\hline $\begin{array}{l}\text { Net calorific value as } \\
\text { received, MJ/kg }\end{array}$ & 13.73 & $4(\geq 10)$ \\
\hline $\begin{array}{l}\text { Chlorine }(\mathrm{Cl}) \text { content in } \\
\text { dry matter, \% }\end{array}$ & 0.138 & $1(\leq 0.2)$ \\
\hline $\begin{array}{l}\text { Hydrargyrum }(\mathrm{Hg}) \\
\text { content, mg/MJ (median) }\end{array}$ & 0.084 & $4(\leq 0.15)$ \\
\hline
\end{tabular}

Evaluating results of the laboratory analysis, the produced SRF was compared to the standard requirements for SRF according to CEN/TC 343. The comparison shows that SRF corresponds to the standard requirements for the recovered fuel (European Committee for Standardization CEN/TR 15508:2006, EN 15359:2011). SRF is attributed to class 4 by the net calorific value, to class 1 by the chlorine $(\mathrm{Cl})$ content in dry matter and to classes 3-4 by the mercury content (see Table 4 ).

In case of addition of $10 \%$ of sawdust or peat into precomposted materials, the $\mathrm{Hg}$ content decreases by 25 - 
$30 \%(0.062-0.066 \mathrm{mg} / \mathrm{MJ})$ and SRF will be attributed to class 3 by the mercury content $(\leq 0.08)$.

\section{Evaluation of air emissions during SRF combustion}

Since the methodology used in Lithuania for evaluation of air emissions (Set of methods 2000) does not include the factors and /or coefficients for the FBC technology, air emissions were evaluated using data of the laboratory analysis of both the SRF chemical composition and limited concentrations $\left(\mathrm{LC}_{\max }\right)$ of air emissions under standard conditions (6\% of oxygen concentration) (Directive 2000/76/EC; BAT for LCP 2006).

The method for evaluation of air emissions during SRF combustion (Gimbutis 1983; Denafas 2000) is presented below.

Correction/revision of the fume flow (discharge) is foremost calculated according to the boiler capacity, fuel calorific value, and the volume of the fuel burnt during the time unit, using formula 3 :

$\mathrm{B}=\mathrm{N} / \mathrm{Q}_{\mathrm{n}}=2.55, \mathrm{~kg} / \mathrm{s}$

where

$\mathrm{N}-\quad$ boiler heat capacity, in our case - $35 \mathrm{MW}$ (or $126 \mathrm{GJ})$;

$\mathrm{Q}_{\mathrm{n}}-\quad$ fuel lower calorific value, $13.73 \mathrm{MJ} / \mathrm{kg}$.

Volume of dry fume $V_{d .}$ dry of the fuel is calculated using formula 4 :

$\mathrm{V}_{\text {d. dry }}=\mathrm{L}_{\text {d. dry }} / \mathrm{B}=8.71, \mathrm{Nm}^{3} / \mathrm{kg}$

where

$\mathrm{L}_{\mathrm{d} \text { dry }}-$ efficiency of the exhauster or the actual dry fume flow (discharge), in our case - 22.22 $\mathrm{Nm}^{3} / \mathrm{s}$;

B - volume of burnt fuel, $\mathrm{kg} / \mathrm{s}$ (see formula 3 ).

Theoretical volume of the air necessary for combustion process $\mathrm{V}^{\mathrm{t}}$ is calculated using formula 5:

$\mathrm{V}^{\mathrm{t}}=0.0889 *\left(\mathrm{C}^{\mathrm{n}}+0.375 * \mathrm{~S}_{\mathrm{d}}{ }^{\mathrm{n}}\right)+0.265 * \mathrm{H}^{\mathrm{n}}-0.0333 * \mathrm{O}^{\mathrm{n}}$

$=3.53, \mathrm{Nm}^{3} / \mathrm{kg}$

where

$\mathrm{C}^{\mathrm{n}}-\quad$ carbon content in fuel, \%;

$\mathrm{S}_{\mathrm{d}}{ }^{\mathrm{n}}-\quad$ combustible sulphur content in fuel, \%;

$\mathrm{H}^{\mathrm{n}}-\quad$ elementary hydrogen content in fuel, \%;

$\mathrm{O}^{\mathrm{n}}-\quad$ oxygen content in fuel, $26 \%$.

Total $\mathrm{CO}_{2}$ and $\mathrm{SO}_{2}$ volume part in fume $\mathrm{V}_{\mathrm{RO} 2}$ is calculated under formula 6 :

$\mathrm{V}_{\mathrm{RO} 2}=0.01866 *\left(C^{\mathrm{n}}+0.375 * \mathrm{~S}_{\mathrm{d}}^{\mathrm{n}}\right)=0.69, \mathrm{Nm}^{3} / \mathrm{kg}$

where

$\mathrm{C}^{\mathrm{n}}-\quad$ carbon content in fuel, \%;

$\mathrm{S}_{\mathrm{d}}{ }^{\mathrm{n}}-\quad$ combustible sulphur content in fuel, $\%$;
Theoretical nitrogen volume part in fume $\mathrm{V}_{\mathrm{N} 2}^{\mathrm{t}}$ is calculated under formula 7 :

$\mathrm{V}_{\mathrm{N} 2}^{\mathrm{t}}=0.79 * \mathrm{~V}_{\mathrm{o}}^{\mathrm{t}}+0.008 * \mathrm{~N}^{\mathrm{n}}=2.80, \mathrm{Nm}^{3} / \mathrm{kg}$;

where

$\mathrm{V}^{\mathrm{t}}{ }_{\mathrm{o}}$ - theoretical volume of the air necessary for the combustion process, for the fuel mass unit $\mathrm{Nm}^{3} / \mathrm{kg}$ (under formula 5);

$\mathrm{N}^{n}-\quad$ nitrogen content in fuel, $\%$.

Water vapors part in fume, not taking into account the moisture excess from the air, $V_{\mathrm{H} 2 \mathrm{O}}^{t}$ is calculated under formula 8 :

$V_{\mathrm{H} 2 \mathrm{O}}^{t}=0.111 * \mathrm{H}^{\mathrm{n}}+0.0124 * \mathrm{~W}^{\mathrm{n}}+0.0161 * \mathrm{~V}^{\mathrm{t}} * \lambda=$ $0.79, \mathrm{Nm}^{3} / \mathrm{kg}$

where

$\mathrm{H}^{\mathrm{n}}-\quad$ hydrogen content in fuel, \%;

$\mathrm{W}^{\mathrm{n}}-\quad$ moisture content in fuel, $15 \%$;

$\lambda$ - $\quad$ air excess coefficient (under formula 13);

$\mathrm{V}_{\mathrm{o}}^{\mathrm{t}}$ - theoretical volume of the air necessary for the combustion process, for the fuel mass unit, $\mathrm{Nm}^{3} / \mathrm{kg}$ (under formula 5).

Total fume volume $V_{d}$ for the burnt fuel volume unit is calculated under formula 9:

$\mathrm{V}_{\mathrm{d}}=\mathrm{V}_{\mathrm{d} \text { dry }}+\mathrm{V}_{\mathrm{H} 2 \mathrm{O}}^{\mathrm{t}}=9.50, \mathrm{Nm}^{3} / \mathrm{kg}$

where

$\mathrm{V}_{\mathrm{d} \text { dry }}$ - dry fume volume calculated using formula 4, $\mathrm{Nm}^{3} / \mathrm{kg}$;

$\mathrm{V}_{\mathrm{H} 2 \mathrm{O}}^{\mathrm{t}}$ - water vapor part in fume, $\mathrm{Nm}^{3} / \mathrm{kg}$ (under formula 8).

Actual fume flow (discharge) $\mathrm{L}_{\mathrm{d}}$ is calculated under formula 10 :

$\mathrm{L}_{\mathrm{d}}=\mathrm{V}_{\mathrm{d}} * \mathrm{~B}=24.225, \mathrm{Nm}^{3} / \mathrm{s}$,

where

$\mathrm{V}_{\mathrm{d}}$ - total fume volume for the burnt fuel volume unit, $\mathrm{Nm}^{3} / \mathrm{kg}$ (formula 9);

B - volume of the fuel burnt during the time unit, $\mathrm{kg} / \mathrm{s}$ (formula 3 ).

Actual fume flow (discharges), e.g. under the conditions of $150{ }^{\circ} \mathrm{C}, \mathrm{m}^{3} / \mathrm{s}$ is calculated under formula 11:

$\mathrm{L}_{\mathrm{d} \text { fact }}=\mathrm{L}_{\mathrm{d}} *(273+\mathrm{T}) / 273=37.54 \mathrm{~m}^{3} / \mathrm{s}$

where

$\mathrm{L}_{\mathrm{d}}$ - actual fume flow (discharge) under normal/standard conditions, $\mathrm{Nm}^{3} / \mathrm{s}$ (formula 10 );

$\mathrm{T}$ - fume temperature, in our case $-150^{\circ} \mathrm{C}$

Actual air excess coefficient $\lambda$ is calculated under formulas 12 and 13 :

$\mathrm{V}_{\mathrm{d}}=\mathrm{V}_{\mathrm{RO} 2}+\mathrm{V}_{\mathrm{N} 2}^{\mathrm{t}}+(\lambda-1) \mathrm{V}_{\mathrm{o}}^{\mathrm{t}}+\mathrm{V}_{\mathrm{H} 2 \mathrm{O}}=9.50 \mathrm{Nm}^{3} / \mathrm{kg}$ 
where

$\mathrm{V}_{\mathrm{RO} 2}$ - total $\mathrm{CO}_{2}$ and $\mathrm{SO}_{2}$ volume part in fume, $\mathrm{Nm}^{3} / \mathrm{kg}$;

$\mathrm{V}_{\mathrm{N} 2}^{\mathrm{t}}-$ theoretical nitrogen volume part in fume, $\mathrm{Nm}^{3} / \mathrm{kg}$

$\mathrm{V}_{\mathrm{H} 2 \mathrm{O}}-$ water vapor volume part in fume, $\mathrm{Nm}^{3} / \mathrm{kg}$;

$\lambda$ - air excess coefficient is calculated under formula 13 :

$\lambda=\left(\left(\mathrm{V}_{\mathrm{d} \text { dry }}-\mathrm{V}_{\mathrm{RO}^{-}}-\mathrm{V}_{\mathrm{N} 2}^{\mathrm{t}}\right) / \mathrm{V}_{\mathrm{o}}^{\mathrm{t}}\right)+1=2.479$

Actual oxygen $\mathrm{O}_{2}$ concentration in dry fume is calculated under formula 14 :

$\mathrm{O}_{2}=21-(21 / \lambda)=12.53$

where

$\lambda$ - actual air excess coefficient.

Actual concentration of air emissions $\left(\mathrm{CO}, \mathrm{NO}_{\mathrm{x}}\right.$, $\mathrm{PM}, \mathrm{SO}_{2}, \mathrm{HCl}$, heavy metals (HM)) are calculated by formula 15 :

$\mathrm{C}^{\mathrm{fact}}=\mathrm{C}^{\mathrm{st}} *\left(21-\mathrm{O}_{2}\right) /\left(21-\mathrm{O}_{2}{ }^{\mathrm{st}}\right)$,

where

$\mathrm{C}^{\text {fact }}$ - actual concentration of pollutant, $\mathrm{mg} / \mathrm{Nm}^{3}$

$\mathrm{C}^{\mathrm{st}}$ - maximum air emission limit concentrations $\left(\mathrm{LC}_{\max }\right)$ under standard conditions, $\mathrm{mg} / \mathrm{Nm}^{3}$ (Directive 2000/76/EC; BAT for LCP):

- CO: $50-250 \mathrm{mg} / \mathrm{Nm}^{3}$ (in our case - 150 $\left.\mathrm{mg} / \mathrm{Nm}^{3}\right)$;

- NOx: 260-400 mg/ $\mathrm{Nm}^{3}$ (in our case - 400 $\left.\mathrm{mg} / \mathrm{Nm}^{3}\right)$;

- PM: 20 - $50 \mathrm{mg} / \mathrm{Nm}^{3}$ (in our case - 50 $\left.\mathrm{mg} / \mathrm{Nm}^{3}\right)$;

- $\quad \mathrm{SO}_{2}: 300$ - $850 \mathrm{mg} / \mathrm{Nm}^{3}$ (in our case -850 $\left.\mathrm{mg} / \mathrm{Nm}^{3}\right)$;

- $\mathrm{HCl}-<25 \mathrm{mg} / \mathrm{Nm}^{3}$ (in our case - 20 $\left.\mathrm{mg} / \mathrm{Nm}^{3}\right)$;

- heavy metals (HM):

- $\quad \Sigma(\mathrm{Sb}, \mathrm{As}, \mathrm{Pb}, \mathrm{Cr}, \mathrm{Co}, \mathrm{Cu}, \mathrm{Mn}, \mathrm{Ni}, \mathrm{V})$ $-0.5 \mathrm{mg} / \mathrm{Nm}^{3}$;

- $\Sigma(\mathrm{Cd}, \mathrm{Ti})-0.05 \mathrm{mg} / \mathrm{Nm}^{3}$;

- $\mathrm{Hg}-0.05 \mathrm{mg} / \mathrm{Nm}^{3}$.

$\mathrm{O}_{2}{ }^{\text {st }}-$ oxygen concentration under standard conditions, $6 \%$;

$\mathrm{O}_{2}-\quad$ actual oxygen concentration in dry fume, $\%$.

Emissions of pollutants $\left(\mathrm{CO}, \mathrm{NO}_{\mathrm{x}}, \mathrm{PM}, \mathrm{SO}_{2}\right.$, $\mathrm{HCl}$, heavy metals) are calculated by formula 16 :

$\mathrm{P}=0.001 * \mathrm{C}^{\mathrm{fakt}} * \mathrm{~L}_{\mathrm{d} \text { dry }}, \mathrm{g} / \mathrm{s}$

where

$\mathrm{C}^{\text {fact }}$ - actual concentration of pollutant, $\mathrm{mg} / \mathrm{Nm}^{3}$ (under formula 15);

$\mathrm{L}_{\mathrm{d} \text { dry }}$ - efficiency of exhauster or the actual dry fume flow (discharge), $\mathrm{Nm}^{3} / \mathrm{s}$.

Calculations of $\mathrm{HCl}$ emissions for sawdust and peat could be made using formula 17 :
$\mathrm{P}_{\mathrm{HCl}}=0.0103 * \mathrm{~B} * \mathrm{Cl}^{\mathrm{n} *}\left(1-\eta^{\circ}{ }_{\mathrm{Cl}}\right), \mathrm{g} / \mathrm{s}$

where

$\mathrm{Cl}^{\mathrm{n}}-\quad$ chlorine content in fuel $\%$;

$\eta^{6}{ }_{\mathrm{HCl}}-\mathrm{HCl}$ part, laced by fuel ash, equated to $\eta^{\circ} \mathrm{sO}$.

Specific air emissions. Knowing the volume of burnt fuel in theory, $\mathrm{kg} / \mathrm{s}$ (under formula 16), and the amount of a certain pollutant emitted to the air $(\mathrm{g} / \mathrm{s})$, it is not difficult to evaluate what amount of the pollutant will be emitted, when burning a certain volume of fuel, i.e. to find the emission factor:

$\mathrm{P}_{\text {factor }}=\mathrm{P} / \mathrm{B}, \mathrm{kg} / \mathrm{t}$

where

$\mathrm{P}$ - $\quad$ amount of emitted pollutant, $\mathrm{g} / \mathrm{s}$;

B - volume of burnt fuel, $\mathrm{kg} / \mathrm{s}$.

Results of calculation of the air emission factor of SRF fluidized bed combustion (FBC) are presented in Table 5 (Kliopova at al. 2010).

Table 5 Emissions of specific pollutant when burning SRF $(F B C), \mathrm{kg} / \mathrm{t}$

\begin{tabular}{||l|l|l|l||}
\hline \hline \multirow{2}{*}{ Emissions } & $\mathrm{C}^{\text {fact }}$ & $\mathrm{P}$ & $\mathrm{P}_{\text {factor }}$ \\
\cline { 2 - 4 } & $\mathrm{mg} / \mathrm{Nm}^{3}$ & $\mathrm{~g} / \mathrm{s}$ & $\mathrm{kg} / \mathrm{t}$ \\
\hline Carbon monoxide $(\mathrm{CO})$ & 84.700 & 1.882 & 0.7381 \\
\hline Nitrogen oxides $(\mathrm{NOx})$ & 225.87 & 5.019 & 1.9681 \\
\hline Dust $(\mathrm{PM})$ & 28.230 & 0.627 & 0.2460 \\
\hline Sulphur oxides $\left(\mathrm{SO}_{2}\right)$ & 479.970 & 10.665 & 4.1823 \\
\hline Hydrogen chloride $(\mathrm{HCl})$ & 11.290 & 0.251 & 0.0984 \\
\hline Heavy metals: & & & \\
$\Sigma(\mathrm{Sb}, \mathrm{As}, \mathrm{Pb}, \mathrm{Cr}, \mathrm{Co}$, & & & \\
$\mathrm{Cu}, \mathrm{Mn}, \mathrm{Ni}, \mathrm{V})$ & 0.280 & 0.006 & 0.0025 \\
$\Sigma(\mathrm{Cd}, \mathrm{Ti})$ & 0.030 & 0.001 & 0.0002 \\
$\mathrm{Hg}$ & 0.030 & 0.001 & 0.0002 \\
\hline \multicolumn{3}{|l}{} \\
\hline
\end{tabular}

Notes:

$C^{\text {fact }}$ - actual concentration of the pollutant, $\mathrm{mg} / \mathrm{Nm}^{3}$ (under formula 15);

$P$-amount of the pollutant emitted, $\mathrm{g} / \mathrm{s}$ (under formula 16);

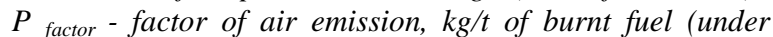
formula 18).

The amount of fuel, required to produce 100 MWh of heat energy was evaluated using formula 19:

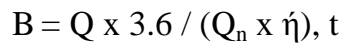

where

B - fuel input, $t$;

Q - produced amount of heat energy, MWh; 1 $\mathrm{MWh}=3.6 \mathrm{GJ}$;

$\mathrm{Q}_{\mathrm{n}}$ - fuel lower calorific value: $15 \mathrm{MJ} / \mathrm{kg}$ - for peat briquettes, $12 \mathrm{MJ} / \mathrm{kg}$ - for sawdust (with $50 \%$ of the moisture content), $13.73 \mathrm{MJ} / \mathrm{kg}-$ for SRG of pre-composted materials;

$\eta$ - heat energy production efficiency factor when burning peat briquettes, $85 \%$ for peat briquettes and SRF combustion and up to 95 $\%$ for sawdust combustion (with condenser economizer) (see Figure 2). 
Table 6 Air emissions ( $t$ ) burning different fuel (sawdust, peat briquettes, SRF) for $100 \mathrm{MWh}$ of heat energy production

\begin{tabular}{||l|l|l|l|l|l|l|l|l||}
\hline \hline Fuel type & Fuel volume, $\mathrm{t}$ & $\mathrm{CO}, \mathrm{t}$ & $\mathrm{SO}_{2}, \mathrm{t}$ & $\mathrm{NOx}, \mathrm{t}$ & $\mathrm{HCl}, \mathrm{t}$ & ${ }^{1} \mathrm{PM}, \mathrm{t}$ & $\mathrm{HM}, \mathrm{t}$ & $\mathrm{CO}_{2}, \mathrm{t}$ \\
\hline Wood sawdust & 31.600 & 0.372 & 0.023 & 0.046 & 0.002 & 0.002 & $0.800^{*} 10^{-4}$ & - \\
\hline Peat briquettes & 28.235 & 0.415 & 0.209 & 0.009 & 0.001 & 0.049 & $0.900^{*} 10^{-4}$ & 44.894 \\
\hline $\begin{array}{l}\text { SRF of pre- } \\
\text { composted materials }\end{array}$ & 30.847 & 0.023 & 0.129 & 0.061 & 0.003 & 0.008 & $0.911^{*} 10^{-4}$ & - \\
\hline
\end{tabular}

Comment:

${ }^{I}$ efficiency of fly ash removable systems: $98.5 \%$ - in case of sawdust burning (due to double treatment: with multi-cyclone and condensate economizer); $90 \%$ - in case of peat fuel burning; $99.5 \%$ - in case of electrostatic filter.

The volume of air emissions during $100 \mathrm{MWh}$ of the heat energy production, burning SRF in comparison to sawdust and peat fuel is presented in Table 6 .

\section{Results of comparison of EIA}

During the production of peat fuel briquettes and SRF pellets different operations are performed. Therefore, the comparison of EIA during peat fuel extraction-production and SRF production is made on the basis of material and energy balances.

Three experiments were carried out in Lithuanian peat production companies for the evaluation of the environmental impact (EA) of the peat extraction process:

- $\quad 1^{\text {st }}$ company in Butku peat-bog (extraction and production capacity -22.5 thousand $\mathrm{m}^{3} /$ year);

- $\quad 2^{\text {nd }}$ company in Galu peat-bog (extraction and production capacity -25.5 thousand $\mathrm{m}^{3} /$ year);

- $3^{\text {rd }}$ company - in Sepetos, Tyrelio, Aliu, Kalniškiu, Pabalves, Lebeliu, Aklaezerio peatbogs (extraction and production capacity - 500 thousand $\mathrm{m}^{3} /$ year).

Using the material and energy balances relative EIs were calculated (see Table 7).

Data of the production of peat fuel briquettes were obtained from the Lithuanian company "Medinukai" Ltd (Staniškis \& Kliopova 2009).

Data of SRF production for material and energy flows are collected from the SRF production line implemented in the Soil-Concept (see Paragraph 2).

EIA of $100 \mathrm{MWh}$ of the heat energy production by burning sawdust is evaluated by the data of material and energy balances from the heat energy production company - "Kretingos šilumos tinklai" Ltd (Kretinga 2012).

Widely applied peat, bio-fuel and SRF combustion technologies have been analyzed:

- for peat and sawdust combustion - grate firing (the oldest firing principle used in boilers) - the technologies of combustion on firegrates - the firegrates of various constructions are used, which can be divided into two groups - static and mechanically activated (most widely applied in the Baltic States);

- for SRF combustion - fluidized bed combustion (FBC) - the combustion in the fluidized bed (bubbling or circulating surfaces are used) (in the Baltic States applied only in large combustion plants (LCP)).
Table 7 Relative EI of peat extraction (Staniškis \& Kliopova 2009)

\begin{tabular}{||l|l||}
\hline Input and output variables & $\begin{array}{l}\text { EI (average } \\
\text { volume of 3 } \\
\text { companies) }\end{array}$ \\
\hline Diesel fuel consumption, $\mathrm{t} / \mathrm{t}$ & 0.01 \\
\hline Air emissions from mobile sources, $\mathrm{kg} / \mathrm{t}$ & 0.98 \\
\hline Additional materials: & \\
\hline Packing (for peat drying), $\mathrm{kg} / \mathrm{t}$ & 0.60 \\
\hline Lubricants and oils, kg/t & 0.30 \\
\hline Tyres, $\mathrm{kg} / \mathrm{t}$ & 0.18 \\
\hline Welding wire, $\mathrm{kg} / \mathrm{t}$ & 0.03 \\
\hline Electrodes, $\mathrm{kg} / \mathrm{t}$ & 0.09 \\
\hline Gas welding, kg/t & 0.02 \\
\hline Waste: & 0.18 \\
\hline Used tyres, $\mathrm{kg} / \mathrm{t}$ & 0.30 \\
\hline $\begin{array}{l}\text { Hazardous waste due to oil and lubricant } \\
\text { consumption, } \mathrm{kg} / \mathrm{t}\end{array}$ & 0.60 \\
\hline $\begin{array}{l}\text { Plastic waste (polyethylene packaging), } \\
\mathrm{kg} / \mathrm{t}\end{array}$ & 0.602 \\
\hline Air emissions during welding, $\mathrm{kg} / \mathrm{t}$ & 0.002 \\
\hline
\end{tabular}

Note: ${ }^{1} t-1$ t of peat.

Usually, thermal efficiency of the peat and biomass combustion plants having no condensing economizers is considered between 80 and $85 \%$, in large combustion plants (LCP) - up to $90 \%$. In case of sawdust combustion, $95 \%$ of thermal efficiency was evaluated due to a condenser economizer. These are the most popular techniques used for enhancing the primary energy (biofuel energy) efficiency in biomass combustion plants in Lithuania (Staniškis at al. 2010, Kretinga 2012).

Main results of EIA of fuels production and combustion for $100 \mathrm{MWh}$ of heat energy production are presented in the comparison Table 8.

The amount of energy in case of SRF production and burning it for the purpose of producing $100 \mathrm{MWh}$ of heat energy is more than 1.4 times higher compared to the peat briquettes production and burning due to the following factors:

- major volume of the moisture content in precomposted materials in comparison to peat before drying;

- briquettes production process requires a smaller volume of electricity in comparison to pellets production: $0.077 \mathrm{kWh} / \mathrm{kg}$ of peat briquettes and $0.164 \mathrm{kWh} / \mathrm{kg}$ of SRF pellets.

The comparison of total energy consumption for the production of $1 \mathrm{~kg}$ of pressing fuel in the drying process of raw materials is presented in the table 9. 
Table 8 Comparison table: main inputs and outputs processes' variables of fuels (sawdust, peat briquettes and SRF pellets) production and combustion for $100 \mathrm{MWh}$ of heat energy production

\begin{tabular}{|c|c|c|c|c|}
\hline \multirow[t]{2}{*}{ 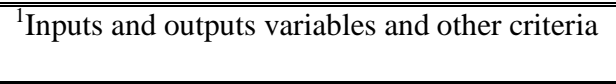 } & \multirow{2}{*}{$\begin{array}{c}\text { Dimen- } \\
\text { sions }\end{array}$} & \multicolumn{3}{|c|}{$100 \mathrm{MWh}$ of heat energy production, burning } \\
\hline & & Sawdust & Peat briquettes & SRF pellets \\
\hline $\begin{array}{l}\text { Fuel characteristics: } \\
\text { Moisture content } \\
\text { Fuel lower calorific value } \\
\text { Volume for } 100 \mathrm{MWh} \text { of heat energy } \\
\text { production }\end{array}$ & $\begin{array}{l}\% \\
\mathrm{MJ} / \mathrm{kg} \\
\mathrm{t}\end{array}$ & $\begin{array}{l}50 \\
12 \\
31.600\end{array}$ & $\begin{array}{l}15 \\
15 \\
28.235\end{array}$ & $\begin{array}{l}15 \\
13.73 \\
30.847\end{array}$ \\
\hline $\begin{array}{r}\text { Main characteristics of combustion plants: } \\
\text { Capacity } \\
\text { Efficiency } \\
\text { Technology }\end{array}$ & $\begin{array}{l}\mathrm{MW} \\
\%\end{array}$ & $\begin{array}{l}<35 \\
95 \\
\text { grate firing } \\
\text { with condenser } \\
\text { economizer }\end{array}$ & $\begin{array}{l}<35 \\
85 \\
\text { grate firing }\end{array}$ & $\begin{array}{l}35 \\
85 \\
\text { FBC }\end{array}$ \\
\hline Main inputs: & & Sawdust & Milled peat & $\begin{array}{c}\text { Pre-composted } \\
\text { materials }\end{array}$ \\
\hline Raw materials moisture content before drying & $\%$ & 50 & 35 & 45 \\
\hline $\begin{array}{r}\text { Raw materials for fuel production: } \\
\text { Before drying } \\
\text { After drying }\end{array}$ & $\mathrm{t}$ & $\begin{array}{l}31.600 \\
31.600\end{array}$ & $\begin{array}{l}37.86 \\
28.950\end{array}$ & $\begin{array}{l}51.68 \\
33.44\end{array}$ \\
\hline $\begin{array}{l}\text { Heat consumption for raw material drying } \\
\text { (fuel consumption for heat energy production) }\end{array}$ & $\begin{array}{l}\text { MWh } \\
(\mathrm{t})\end{array}$ & - & $\begin{array}{l}7.89 \\
(1.89-\text { peat } \\
\text { briquettes })\end{array}$ & $\begin{array}{l}11.65 \\
(3.59-\mathrm{SRF})\end{array}$ \\
\hline $\begin{array}{l}\text { Electricity consumption for raw material drying } \\
\text { (in dryer; } 1 \mathrm{t} / \mathrm{h} ; 60 \mathrm{~kW} ; \text { load }-70 \% \text { ) }\end{array}$ & MWh & - & 1.590 & 2.170 \\
\hline $\begin{array}{l}\text { Electricity consumption for the main } \\
\text { technological process (pressing) }\end{array}$ & MWh & - & $\begin{array}{l}2.174 \\
(0.077 \mathrm{kWh} / \mathrm{kg})\end{array}$ & $\begin{array}{l}.059 \\
(0.164 \\
\mathrm{kWh} / \mathrm{kg})\end{array}$ \\
\hline $\begin{array}{l}\text { Electricity consumption in combustion plant } \\
\text { (in case of sawdust - in combustion plant, and } \\
\text { in economizer) }\end{array}$ & MWh & $\begin{array}{l}1.9 \\
(18.74 \\
\mathrm{kWh} / \mathrm{MWh})\end{array}$ & $\begin{array}{l}1.3 \mathrm{kWh} / \mathrm{MWh}) \\
(13 \mathrm{~kW}\end{array}$ & $\begin{array}{l}1.8 \\
(18 \\
\mathrm{kWh} / \mathrm{MWh})\end{array}$ \\
\hline $\begin{array}{l}\text { Other energy, inc. diesel furl consumption, for } \\
\text { example, for pre-composted materials mixing } \\
\text { and screening, for peat extraction, for all fuel } \\
\text { loader within the combustion plant }\end{array}$ & MWh & 0.2 & 4.015 & 2.952 \\
\hline Total energy consumption: & MWh & 2.100 & 16.969 & 23.631 \\
\hline Rape-oil (additional material for SRF) & $\mathrm{t}$ & - & - & 0.389 \\
\hline $\begin{array}{l}\text { Materials for condensate from economizer } \\
\text { neutralization }\end{array}$ & $\mathrm{t}$ & $\begin{array}{l}0.006 \\
(0.06 \mathrm{~kg} / \mathrm{MWh})\end{array}$ & - & - \\
\hline $\begin{array}{l}\text { Sand consumption for "fluidized layer" } \\
\text { addition }\end{array}$ & $\mathrm{t}$ & - & - & 0.31 \\
\hline Matrix consumption & Units & - & $\begin{array}{l}0.007 \\
\text { (1 unit / } 4000 \mathrm{t} \text { of } \\
\text { peat briquettes) }\end{array}$ & $\begin{array}{l}0.04 \\
(1 \text { unit / } 800 \mathrm{t} \\
\text { of pellets) }\end{array}$ \\
\hline Main outputs: & & & & \\
\hline Heat energy production & MWh & 100 & 100 & 100 \\
\hline Heat energy losses during production & MWh & 5.33 & 17.65 & 17.65 \\
\hline $\begin{array}{l}\text { Air emissions during fuel burning for } 100 \\
\text { MWh of heat energy production (see Table 3) } \\
\text { and drying process (only for peat and compost) } \\
\text { PM, inc. } \mathrm{HM} \\
\mathrm{CO} \\
\mathrm{NO}_{\mathrm{x}} \\
\mathrm{SO}_{2} \\
\mathrm{HCl}_{2} \\
\mathrm{CO}_{2}\end{array}$ & $\mathrm{t}$ & $\begin{array}{l}0.445 \\
\\
0.002, \text { inc. } \\
0.00008 \\
0.372 \\
0.046 \\
0.023 \\
0.002 \\
{ }^{2} 0 \\
\end{array}$ & $\begin{array}{l}0.729 \text { and } 47.904 \text { of } \\
\mathrm{CO}_{2} \\
\\
0.052, \text { inc. } 0.000096 \\
0.443 \\
0.010 \\
0.223 \\
0.001 \\
47.904\end{array}$ & $\begin{array}{l}0.248 \\
\\
0.008, \\
\text { inc. } 0.0001 \\
0.025 \\
0.068 \\
0.144 \\
0.003 \\
{ }^{2} 0 \\
\end{array}$ \\
\hline $\begin{array}{l}\text { Indirect impact: air emissions during electricity } \\
\text { consumption (for example, burning natural } \\
\text { gas): } \\
\qquad \mathrm{CO}: \\
\mathrm{NOx}: \\
\mathrm{CO}_{2}\end{array}$ & $\mathrm{t}$ & $\begin{array}{l}0.002 \\
0.001 \\
0.454\end{array}$ & $\begin{array}{l}0.009 \\
0.003 \\
1.957\end{array}$ & $\begin{array}{l}0.011 \\
0.004 \\
2.584\end{array}$ \\
\hline $\begin{array}{l}\text { Particulate matters' (PM) emissions to the air } \\
\text { during fuel production (pressing) }\end{array}$ & $\mathrm{t}$ & - & 0.136 & 0.966 \\
\hline
\end{tabular}




\begin{tabular}{|c|c|c|c|c|}
\hline \multirow[t]{2}{*}{${ }^{1}$ Inputs and outputs variables and other criteria } & \multirow{2}{*}{$\begin{array}{c}\text { Dimen- } \\
\text { sions }\end{array}$} & \multicolumn{3}{|c|}{$100 \mathrm{MWh}$ of heat energy production, burning } \\
\hline & & Sawdust & Peat briquettes & SRF pellets \\
\hline $\begin{array}{r}\text { Non-hazardous waste } \\
\text { ash from treatment equipment, } \\
\text { bottom ash and remains } \\
\text { production losses; } \\
\text { sand with slag from FBC } \\
\text { metal waste }\end{array}$ & $\mathrm{t}$ & $\begin{array}{l}0.316 \\
0.131 \\
0.185\end{array}$ & $\begin{array}{l}3.148 \\
0.468 \\
2.101 \\
0.579 \\
- \\
-\end{array}$ & $\begin{array}{l}10.752 \\
1.69 \\
7.806 \\
0.308 \\
0.300 \\
0.648\end{array}$ \\
\hline Waste water (neutralized condensate) & $\mathrm{m}^{3}$ & 40 & - & - \\
\hline
\end{tabular}

Notes:

${ }^{I}$ The assumption has been accepted that consumption of water and technical salt for water softening is the same for all fuels; therefore it is not shown in this table;

${ }^{2}$ Due to biogenic nature of the sawdust and SRF.

Table 9 Total energy consumption for the production of $1 \mathrm{~kg}$ of fuel (comparison table)

\begin{tabular}{|c|c|c|}
\hline \multirow[t]{2}{*}{ Energy: } & \multicolumn{2}{|c|}{ Energy consumption, $\mathrm{kWh} / \mathrm{kg}$} \\
\hline & $\begin{array}{l}\text { SRF } \\
\text { (pellets) }\end{array}$ & $\begin{array}{l}\text { Peat fuel } \\
\text { (briquettes) }\end{array}$ \\
\hline $\begin{array}{l}\text { Diesel fuel: } \\
\text { for mixing: } \\
\text { for extraction: }\end{array}$ & $\begin{array}{l}0.095 \\
-\end{array}$ & $\begin{array}{l}- \\
0.119\end{array}$ \\
\hline $\begin{array}{l}\text { Heat energy for raw } \\
\text { material drying }\end{array}$ & 0.225 & 0.208 \\
\hline $\begin{array}{l}\text { Electricity } \\
\text { for drying: } \\
\text { for pressing: }\end{array}$ & $\begin{array}{l}0.042 \\
0.164\end{array}$ & $\begin{array}{l}0.042 \\
0.077\end{array}$ \\
\hline Total & 0.526 & 0.446 \\
\hline
\end{tabular}

It is evaluated that approx. $50 \mathrm{~kg}$ of peat briquettes are usually used for $1 \mathrm{t}$ of peat drying (from $35-40$ to $15 \%$ of the moisture content). In case of analyzed SRF it is evaluated that approx. $18.2 \mathrm{~m}^{3}$ of water must be evaporated from the evaluated volume of the pre-composted materials; energy consumption $0.64 \mathrm{kWh}$ for the elimination of 1 liter of water.

The volume of air emissions during SRF burning is the smallest, because of strong requirements for the SRF combustion techniques, the maximum air emission limit concentrations $\left(\mathrm{LC}_{\max }\right)$ under standard conditions, $\mathrm{mg} / \mathrm{Nm}^{3}$ (Directive 2000/76/EC; BAT for LCP), etc.

The volume of air emissions during peat briquettes burning is considerably larger compared to the emissions of burning sawdust or SRF. This is due to carbon dioxide emissions that are calculated only for fossil fuel.

Total air emissions for $100 \mathrm{MWh}$ of heat energy production, burning fuel, inc. fuel production and indirect impact due to electricity consumption are:

- $\quad$ in case of sawdust $-0.902 \mathrm{t} / 100 \mathrm{MWh}$, inc. $0.454 \mathrm{t} \mathrm{CO}_{2} / 100 \mathrm{MW}$;

- $\quad$ in case of peat briquettes - $50.602 \mathrm{t} / 100 \mathrm{MWh}$, inc. $49.861 \mathrm{t} \mathrm{CO}_{2} / 100 \mathrm{MW}$;

- $\quad$ in case of SRF - 2.847 t/100 MWh, inc. $2.584 \mathrm{t}$ $\mathrm{CO}_{2} / 100 \mathrm{MW}$.

The volume of waste in case of SRF production is larger in comparison to other fuel, because of the high ash content in raw material: more than $30 \%$ in dry matter. Therefore, about $30 \%$ of SRF of compost or about $18 \%$ of the volume of initial raw materials (compost) becomes waste (ash, bottom ash and remains).
It can be concluded that a higher environmental impact will be in the case of SRF production and combustion, but it should be noted that SRF used for energy production minimizes carbon dioxide emissions, saves energy and raw material resources, and the land required for waste disposal.

\section{Conclusions and recommendations}

The use of peat for fuel has a long tradition in EU countries, inc. Lithuania. But, during the period of last 10 years peat consumption for energy production was constantly decreasing in Lithuania. Two main reasons were determined: technical and environmental (Staniškis \& Kliopova 2009). The first one is a huge volume of $\mathrm{CO}_{2}$ emissions, a rather large volume of $\mathrm{SO}_{2}$ and $\mathrm{PM}$ emissions during peat fuel combustion in comparison to the other fuel used. Furthermore, suitable combustion techniques were not implemented. In Lithuania biofuel (firewood and sawdust, in particular) makes main part of renewable energy resources. Both fuels (peat fuel and bio fuel) are solid fuel and local energy resources. Therefore, those fuels were chosen for the comparative analysis for the EIA of SRF of compost production and combustion for heat energy production.

A net calorific value of SRF in the form of a pellet made of 10-40 mm fraction of pre-composted materials in the Soil - Concept company with $15 \%$ of the moisture content is about $13-14 \mathrm{MJ} / \mathrm{kg}$. It corresponds to the net calorific value of the nonpressed sawdust with $30 \%$ of the moisture content $(12.52 \mathrm{MJ} / \mathrm{kg})$ and peat briquettes with $15 \%$ of the moisture content $(15 \mathrm{MJ} / \mathrm{kg})$.

As a result of the evaluations of chemical characteristics, we can conclude that pre-composted materials can be mixed with peat or sawdust for improving SRF characteristics. For example, in case of mixing with sawdust (up to $10 \%$ of raw material volume), the ash content decreases by approx. 2 times, heavy metals- by 1.2 times, $\mathrm{Cl}, \mathrm{S}$ and $\mathrm{N}-$ by approx. 1.5 times (see Table 3, Composition II ).

And, similarly, with the purpose to improve some characteristics of peat fuel, for example, to reduce some nitrogen $(\mathrm{N})$ content in fuel, or $\mathrm{CO}_{2}$ emissions to the air, peat could be mixed with precomposted materials.

Evaluating results of the laboratory analysis, the produced SRF was compared to the standard 
requirements for SRF according to CEN/TC 343 (see Table 4). The comparison shows that produced SRF of pre-composted materials (fraction - 10-40 $\mathrm{mm}$ ) in the pellet form corresponds to:

class 4 by the net calorific value $(\mathrm{MJ} / \mathrm{kg})$,

class 1 by the chlorine $(\mathrm{Cl})$ content in dry matter, and

classes 3-4 by the mercury content (mg/MJ).

When applying EIA of the fuel production, the energy consumption per unit of fuel was evaluated (see Table 9) as follows:

in case of SRF in the pellet form production $0.526 \mathrm{kWh} / \mathrm{kg}$, inc. $0.164 \mathrm{kWh} / \mathrm{kg}$ - for a pelletizing process;

- in case of peat fuel in the briquette form production - $0.446 \mathrm{kWh} / \mathrm{kg}$, inc. a peat extraction process

A fair amount of metal waste and other solid additives could be found in pre-composted materials. Therefore, it is necessary to remove stones, metal waste, wood parts $(>20 \mathrm{~mm})$, etc, which could damage technological lines for production of pellets.

In order to optimize the heat energy production process and to reduce environmental impact during SRF burning, complex combustion technologies (for example, FBC, CFBC) have to be applied and, in terms of economical return, they are usually recommended to large fuel combustion plants.

During the analysis of SRF combustion parameters, it was evaluated that the excess air coefficient (factor) should be maintained at its minimum value of 2.4 in the SRF combustion plant (see Paragraph 5). Also, due to high dust air emission, plants for solid particles treatment have to be installed.

Positive aspects of EIA of SRF production and combustion are the following:

$82 \%$ of biodegradable waste, inc. sludge of municipal waste water treatment plant and green waste (raw materials for SRF production) are convertible to the energy; $18 \%$ of mass becomes waste (ash, bottom ash, and remains);

- the amount of energy needed for the SRF production and combustion does not exceed that obtained during SRF combustion (23.631 $\mathrm{MWh} / 100 \mathrm{MWh}$ );

- the volume of $\mathrm{CO}_{2}$ emitted during SRF combustion equates zero due to biogenic nature of raw materials used in SRF production;

- total air emissions during the heat energy production burning SRF of pre-composted materials, inc. the SRF production process and indirect impact due to electricity consumption are 2.8 times lower than the air emissions during peat briquettes production (excluding $\mathrm{CO}_{2}$ ) and over 17 times lower in case of $\mathrm{CO}_{2}$ evaluation (see Table 8).

Negative aspects of EIA of the SRF production and combustion are the following:

SRF of pre-composted materials results in the high ash content (more than 30\%); therefore PM emissions to the air during SRF combustion after treatment before $99.5 \%$ are four times higher, compared to the sawdust combustion (see Table 6);

the heavy metals content in pre-composted materials is more than 17 times higher, compared to the sawdust and about 6 times higher, compared to the peat;

- the amount of total energy needed for the SRF pellets production and its combustion for 100 MWh of heat energy production is 1.4 times higher compared to the peat briquettes production and combustion, and more then 11 times higher compared to the sawdust combustion (see Table 8).

Despite the negative aspects, the results of this study show that SRF of pre-composted materials (fraction 10-40 mm), made of BD waste (stabilized sludge of municipal waste water treatment plant and green waste) can be used as an alternative energy recourse. For the purpose of reducing an environmental impact on the air, first of all, chemical and physical characteristics of separate pre-composted materials fractions are to be evaluated for discovering more suitable ones for fuel production for each parcel. Besides, pre-composted materials can be mixed with sawdust (up to $10 \%$ of the total SRF raw materials volume) or SRF can be burnt together with biofuel. There are two possible approaches, when mixing precomposted materials with sawdust, namely:

- SRF is an alternative fuel. If sawdust is added, burning characteristics of the SRF improve, the impact on the environment decreases;

- Proper BD waste utilization with a minimal impact on the environment. BD waste is added into the sawdust with the purpose of utilizing BD waste and producing energy.

There is no point in substitution peat fuel by recovered fuel. Peat fuel is not classified as alternative energy resource - it is local energy recourse. The socio-economic impact of this fuel is significant for some EU countries (for example, Finland, Island) and in these countries BAT technologies are applied to the peat fuel burning, and, thus, energy efficiency is increased, while EI is decreased.

In case of adding peat fuel to raw materials for SRF production, some peat fuel characteristics are improved: NOx, $\mathrm{CO}_{2}$ emissions to the air decrease. Furthermore, peat fuel can improve some recovered fuel characteristics: increase the calorific volume, decrease energy consumption for raw materials drying. In case of mixing pre-composting materials with peat, the briquettes production becomes more proper from economical and environmental point of view.

\section{References}

A. Kelessidis, A. S. Stasinakis. Comparative study of the methods used for treatment and final disposal of sewage sludge in European countries. Waste management 32. 2012.

Fuel and energy balance. 2011. Statistics Lithuania. 
ENERCOM. Summary and objectives of Collaborative project Polygeneration of energy, fuels and fertilizers from biomass residues and sewage sludge. Coordinator Institut für angewandtes Stoffstrommanagement (IfaS). 2008-2012. http://www.enercom.stoffstrom.org

Fuel peat industry in EU. Summary report, 2006.

Teuvo Paappanen. Peat Industry In The Six EU Member States - Country Reports: Finland, Ireland, Sweden, Estonia, Latvia, Lithuania. Research report 2010.

I. Kliopova, K. Makarskienè. Generation of Solid Recovered Fuel from Sewage Sludge Compost. Environmental research, engineering and management, No. 4(62), 2012. P. 39-51.

Soil-Concept, KTU APINI. Publishable summary of WP4 Generation of fuel (DEM) (Del. 22) Pelleting press monitoring report. ENERCOM. 2010.

I. Kliopova, J.K. Staniškis, A. Laurinkevičiūtè. Publishable summary of WP3 Generation of fuel (Del. 19) Study on peat substitution potential of compost pellets. ENERCOM. 2010

I. Kliopova, A. Laurinkevičiūtè. Publishable summary of WP3 Generation of fuel (Del. 16) Pellets and briquettes feasibility study. ENERCOM. 2009

J.K. Staniškis, I. Kliopova, Publishable summary of WP3 Generation of fuel (Del. 18) Briquetting test report. ENERCOM. 2009

I. Obernberger, T. Brunner, A. Polzer. BIOS. Publishable summary of WP2 Generation of raw materials (Del.10). Report on input fuel analysis. ENERCOM. 2009.

G. Gimbutis, K. Kajutis, V. Krukonis, A. Pranckūnas, P. Švenčianas. Thermal technique -Mokslas, 1983. - 333 p.

Denafas, G. Atmosphere protection (I). Results of air pollutions and control. Educational book. Kaunas. "Technologija", 2000. P. 88

The list of methodologies for the evolution of air emissions, approved by the Ministry of Environment of the Republic of Lithuania (13-12-1999 No. 395, last addition in 2008).

Set of methods for the calculation of air emissions from the different production process. Evaluation of air emissions burning different fuel in combustion plants with capacity less than $30 \mathrm{t} / \mathrm{h}$. Gostkomgidromet. Leningrad, 1986 (last addition - in 2000).

Staniškis, J.K., Stasiškienè, Ž., Kliopova, I., Varžinskas, V. Sustainable innovations in Lithuanian
Industry: Development and Implementation, P. 458. Technologija, Kaunas, 2010. P.223-297.

Directive 2000/76/EC of the European parliament and of the council of 4 December 2000 On the iincineration of waste.

European Commission. IPPC Draft Reference Document on Best Available Techniques (BAT) for Large Combustion Plants (LCP), July, 2006

European Committee for Standardization. Technical Committee 343 Solid Recovered Fuels (CEN TC 343). EN 15359:2011. Solid recovered fuels - Specifications and classes, 2011. Brussels. CEN.

European Committee for Standardization Technical Committee 343 Solid Recovered Fuels (CEN TC 343). CEN/TR 15508:2006. Key properties on solid recovered fuels to be used for establishing a classification system, 2006, Brussels. CEN.

IPPC permit of "Kretingos šilumos tinklai" Ltd. 2012.

Dr. Irina Kliopova, Associated prof., Institute of Environmental Engineering, Kaunas University of Technology.

Main research areas: EIA; IPPC; CP through process control; biodegradable waste management; energy efficiency and alternative energy production.

Address: $\quad$ Teatro str. 8-16, Vilnius,

LT-03107 Lithuan

Tel./fax: $\quad+370-5-2649174$

E-mail: $\quad$ irina.kliopova@ktu.lt

MSc. Kristina Makarskienè, Institute of Environmental Engineering, Kaunas University of Technology

Main research areas: Cleaner Production, biodegradable waste management, alternative energy production.

Address: $\quad$ K. Donelaičio str. 20, Kaunas

LT-44239 Lithuania

Tel.: +370-616-03576

E-mail: $\quad$ kristina.makarskiene@gmail.com 


\title{
Kietojo atgautojo kuro gamyba iš atskirų frakcijų pirminio komposto, pagaminto iš buitinių nuotekų dumblo ir biomasės liekanų
}

\author{
Irina Kliopova, Kristina Makarskienè \\ Aplinkos inžinerijos institutas, Kauno technologijos universitetas
}

(gauta 2013 m. balandžio mèn.; atiduota spaudai 2013 m. birželio mèn.)

Lietuvoje, kaip ir visuose ES šalyse, ieškoma būdų, kaip efektyviai spręsti buitinių nuotekų valymo ỉrenginiu dumblo utilizavimo problemą. Šiuo metu plačiai analizuojamos galimybès naudoti degazuotą dumblą kietojo atgautojo kuro (KAK) gamybai. Bet laboratorinių analizių tyrimai rodo, kad drẻgnas dumblas nepasižymi didelëmis žemutinės šiluminès vertės charakteristikomis; dumblui džiovinti reikalingos didelès investicijos ir energijos sąnaudos. Kai kuriuose ES šalyse (pvz. ,Vokietijoje, Austrijoje, Liuksemburge ir kt.) nuoteku dumblas po anaerobinio apdorojimo kompostuojamas, ji maišant su anglimi (C) turtingomis medžiagomis, pvz., biomasès liekanomis.

Nuo $2008 \mathrm{~m}$. KTU APINI darbuotojai dalyvauja 7 BP programos projekte „Energijos, kuro ir trąsų gamyba iš biomasès liekanų ir nuotekų dumblo“ (ENERCOM) (Nr. TREN/FP7/EN/218916). Viena iš projekte analizuojamų temų - pirminio komposto (po žaliavų sumaišymo ir aerobinio apdorojimo - 3 savaites, naudojant biodžiovinimo principus) naudojimas KAK gamybai. Kompostas gaminamas Liuksemburgo i̇monèje „Soil Concept“ naudojant klasikinę kompostavimo technologiją su priverstiniu oro padavimu. Komposto žaliava - iš buitinių nuotekų valymo irenginių degazuotas ir iki 75-80 proc. nusausintas dumblas ir biomasès liekanos: parku, mišku, vadinamosios žaliosios atliekos, kurių drégnis siekia apie 50-55 proc., masė - apie 50 proc. žaliavos masės. KAK gamybos ivvykdomumo analizės rezultatai jau buvo paskelbti [Kliopova ir Makarskienė 2012].

Atliekant minèto pirminio komposto ivvairiu frakcijų cheminių ir fizikinių parametrų tyrimus, buvo pastebėta, kad pirminio komposto frakcija nuo 10 iki $40 \mathrm{~mm}$ pasižymi savybėmis, geriausiai tinkamomis KAK gamybai. Šiuo atveju sijojimą galima atlikti jau po 3 kompostavimo savaičiu Kompostuojant masé išdžiovinama iki $\sim 50$ proc. dreggnio. Mišinio frakcija iki $10 \mathrm{~mm}$ toliau kompostuojama ir naudojama trąšu gamybai. Mišinio frakcija per $40 \mathrm{~mm}$ kaip struktūrinè medžiaga naudojama tolesniam kompostavimui.

Vykdant tyrima, „Soil Concept“ imonėje stebèta įdiegtos KAK (pirminio komposto granuliu) gamybos iranga, išanalizuoti visi gamybos proceso etapai (nuo žaliavos paruošimo iki granuliu svèrimo ir pakavimo) ir jų îvediniai ir išvediniai, sudarytas proceso medžiagų ir energijos balansas, ivertinti santykiniai aplinkosaugos indikatoriai (žr. 1 pav., 1 lent.). Gauti rezultatai panaudoti ivertinus durpių kuro bei pjuvenų pakeitimo KAK galimybes. Durpès - plačiai naudojamos kaip vietinis kuras tokiose ES šalyse, kaip Suomija, Švedija, Airija, Estija. Birios pjuvenos plačiausiai naudojamos Lietuvoje kaip atsinaujinantys šilumos energijos ištekliai. Tyrime buvo atliktas poveikio aplinkai vertinimas ir lyginamoji analizè. Analizuojami procesai: šilumos energijos (100 MWh) gamyba deginant KAK, durpių kurą ir birias pjuvenas, issk. KAK (granulių forma) gamyba, durpiu išgavimą ir durpių kuro (briketu) gamyba. Pjuvenos ir KAK vertinamos kaip procesu atliekos, todèl jų išgavimas neanalizuojamas. Ypatingas dèmesys skiriamas poveikio aplinkos orui vertinimui, kuro - energijos balansui.

Analizuojant KAK deginimo poveiki aplinkos orui, buvo naudojami BIOS BIOENERGIESYSTEME GmbH [BIOS 2009] atliktu 10-40 mm pirminio komposto frakcijos cheminès sudèties bei fizikinių parametrų laboratorinių tyrimų rezultatai (žr. 2 lent.).

Straipsnyje pateikti visu atliktu tyrimų rezultatai, apibendrinančios išvados ir rekomendacijos: aprašyta „Soil Concept“ imonèje idiegta KAK (granuliu forma) gamybos technologija ir procesu santykiniai indikatoriai; palyginta analizuojamo pirminio komposto laboratoriniu būdu nustatyta cheminè sudètis su durpių kuru ir biriu pjuvenų chemine sudètimi; teoriškai ịvertinta su pjuvenomis arba durpių kuru maišyto pirminio komposto cheminè sudètis; deginant KAK nustatyti išskiriamų degimo produktų emisijų veiksniai $(\mathrm{kg} / \mathrm{t})$; palygintos išlakos aplinkos orą deginant KAK, durpiu kurą ir pjuvenas, naudojant kiekvienam kurui geriausiai prieinamą deginimo technologija; nustatytas energijos kiekis ( $\mathrm{MWh}$ ), reikalingas KAK gamybai bei deginimui tam, kad būtu pagaminta $100 \mathrm{MWh}$ šilumos energijos (žr. 9 lent.); pateikti kiti poveikio aplinkai vertinimo rezultatai (žr. 8 lent.). 